\title{
SMEs in the Malaysian Economy
}

\author{
Mohammad Ziaul Hoq \\ Faculty of Business and Accountancy, University of Malaya \\ Kuala Lumpur, Malaysia \\ E-mail: hoq.ziaul@gmail.com \\ Norbani Che Ha \\ Faculty of Business and Accountancy, University of Malaya \\ Kuala Lumpur, Malaysia \\ Saad Mohd Said \\ Faculty of Economics and Administration, University of Malaya \\ Kuala Lumpur, Malaysia
}

\begin{abstract}
This study provides comprehensive analysis of the contribution of and challenges facing SMEs in the Malaysian economy. In particular, it looks at the contribution of the SMEs to create employment opportunities and provide stimulus to economic growth, backward and forward linkages, expanding entrepreneurial bases and developing human capital. The study also outlines the challenges and opportunities faced by Malaysian SMEs in an increasingly globalized world.
\end{abstract}

Keywords: SMEs, Malaysian Economy

\section{Introduction}

In many countries, SMEs play an important role in the country's economic development. In Malaysia, for example, the statistics from SMIDEC (2002) indicates that 93.8 percent of companies in the manufacturing sector are SMEs and they contributed 27.3 percent to total manufacturing output, 25.8 percent to value-added production, own 27.6 per cent of fixed assets and employ 38.9 per cent of the country's workforce. It is forecast that by 2020 , the value-added products from SMEs will be worth RM 120 billion or 50 percent of total production in the manufacturing sector.

The importance of SMEs in Malaysia can be traced back to the early 1970s with the implementation of the New Economic Policy (NEP) in 1971 which aimed to improve people's welfare and restructure ethnic economic imbalances. The commitment of Malaysian Governments to develop SMEs was further strengthened by the implementation of the Malaysia Industrial Master Plan, particularly the Industrial Master Plan 2 or IMP2 from 2000 to 2005 which was followed by the IMP3 spanning 2006 to 2020 . Among other policies, this plan coincides with the country's vision to be a developed nation by 2020 (MITI, 2005).

Various policies and strategies have been and will be implemented under these plans. In particular, the IMPs were formulated to enhance the growth of the manufacturing sector across the entire value chain and cluster-based industrial developments. Using an integrated approach, the Malaysian government aims to develop SMEs from the start up stage with lower levels of technology through to the maturity stage and thus enable them to globally compete with other SMEs at that level.

\section{SMEs in Malaysia - Contribution to Malaysian Economy}

\subsection{The Macroeconomic Environment}

It is useful to place the economic contribution of SMEs in Malaysia in the context of the wider picture of the economy. Therefore, a review of sector contributions to GDP, employment and export of manufactured products is provided prior to the detailed analysis of the contribution of SMEs in the manufacturing and the service sectors.

\section{i. Contribution to GDP by Sector}

Table 1 highlights the contribution of sectors to Gross Domestic Product.

\section{Insert table 1 here}


From Table 1, it is obvious that the service sector contributed more than half of GDP. For example, the contribution of the service sector increased from a share of 50.7 per cent in 1996 to 58.1 per cent in 2005. Over the same period, the contribution of the manufacturing sector also increased from 29.1 per cent in 1996 to 31.4 per cent in 2005. The construction sector experienced a significant decline in its contribution to GDP from 4.7 per cent in 1996 to 2.7 per cent in 2005, reflecting the impact of the Asian Financial Crisis in 1997 from which it had not recovered.

\section{ii. Contribution to Employment}

Table 2 shows the share of employment by economic sectors in 1996, 2000 and 2005 and the respective percentage annual growth rates of employment over the period 1996 - 2005. For example in 2005, total employment in Malaysia was 10.89 million, with the service sector contributing about a half (51\%) of total employment followed by the manufacturing sector $(28.7 \%)$. Both sectors also indicated a positive growth rate in employment from $1996-2005$. In contrast, the growth rate in employment in the other sectors is negligible and even negative in the case of the agriculture, forestry and fishery sector (- 0.6 per cent). This significant decline in the growth rate of employment by this latter sector is indicative of its declining importance to the Malaysia economy.

\section{Insert table 2 here}

\section{iii. Contribution to Export by Sectors}

Table 3 indicates the share of manufactured exports by industry in 1996, 2000 and 2005. The export of non-resource based manufactured products is dominant with, for example, a share of 82.4 per cent in 2005 compared with only 15.3 per cent from the resource based industries. The leading export industry, amongst the non-resource based industries, was electrical and electronics products with a 64.1 percentage share of manufactured exports in 2005 . For the resource based industries, as indicated in Table 3, the chemical \& chemical products industry was the leading industry with a 6.4 percentage share of exports of manufactured products in 2005.

\section{Insert table 3 here}

\subsection{SMEs in the Manufacturing Sector}

The majority of establishments in Malaysia either in the manufacturing, service or agricultural sectors are SMEs. For example in 2003, from the total establishments in the service sector, 99.4 per cent were SMEs, followed by 99.2 per cent in the agricultural sector and 96.6 per cent in manufacturing. Given the declining importance of the agricultural sector in the macro-economy of Malaysia, the discussion will focus first on SME establishments in the manufacturing sector and then in the service sector.

Table 4 outlines the profile of the SMEs in the manufacturing sector by industrial origin. It is evident that Malaysian SMEs are involved in a wide range of activities, from simple processing and production of raw materials to assembling and manufacturing of electrical and electronics appliances and components.

\section{Insert Table 4 here}

\section{i. Contribution of SMEs to Manufacturing Output and Value Added}

Table 5 presents the contribution of SMEs in terms of share of manufacturing output and value added, as well as the annual growth rates of SMEs' total output and value added. It is clear that while maintaining its share of manufacturing sector output at 29.1 per cent over 2002 and 2003, the annual growth rate of SMEs manufacturing output has been a positive 9.7 per cent over 2002-2003. For the value added, its share has slightly increased with a healthy annual growth rate of value added of 11.8 per cent.

\section{Insert Table 5 here}

Further disaggregation, by industry, of the SME contribution to manufacturing output, growth in output, value-added and growth in value-added is provided in Table 6. The SME share of manufactured output by industry was largest in the food and beverage industry (30.6 per cent), followed by metal and metal products at 13.6 per cent and chemical and chemical products at 11.9 per cent. The decline in the output of motor vehicles and transportation were due to the anticipation of tariff reductions as a result of the ASEAN Free Trade Agreement (AFTA). Consumers withheld purchases because of uncertainty, and this affected the SME supply of parts and components.

\section{Insert Table 6 here}

\section{ii. Contribution of SMEs to Employment and Productivity}

Table 7 presents the SME share of employment and the growth rate of that employment by industry. Thus SMEs accounted for 16.6 per cent of employment in food and beverages, with employment provided by SMEs in this industry growing at a rate of 3.5 per cent. For wood and wood products, the SME share of employment was 16.2 per cent with SME employment growing at a rate of 13.3 per cent. In rubber and plastic products the employment share was 13.1 per cent. 
Employment opportunities with SMEs in the food and beverages industry are facilitated by the low barriers to entry and the growing opportunities in the halal food market, which the Malaysian government actively encourages SMEs to take advantage of. In the wood and wood products industry, the high growth rate of SME employment (13.3 per cent) is due to the improvement in higher-end products, increases in capital intensity and improvements in process efficiency. This is also accompanied by the high demand from the export market for Malaysian wood products, particularly the export of wooden furniture. For the rubber and plastic products industry, the SME employment share remains strong as the consumption of rubber products, in particular, remains steady as there is no perfect substitute for natural rubber and the US still remains as the major rubber consuming nation. Note also that the SME employment share in the metal and metal products industry is strong (12.9 per cent) due to the high export demand for iron and steel products. Similarly, there is strong growth rate of SME employment in Chemicals. However, there is negative employment growth rate in textiles and machinery.

\section{Insert Table 7 here}

Table 8 reports the labor productivity of SMEs in 2003. As reported by the National Productivity Corporation (2004), there was an increase in labor cost per employee of 7.3 per cent, marginally less than the increase in value added per employee of 7.8 per cent. This implies that the labor market in Malaysia was tight, a contention which is supported also by the reduction in the average unemployment rate from 6.1 per cent for $1970-1979$ to 3.3 per cent for $1990-1999$. (Fatimah \& Saad, 2002). Thus, further improvement of SMEs competitiveness requires an effective reduction in unit labor cost.

\section{Insert Table 8 here}

\subsection{SMEs in the Services Sector}

According to the Department of Statistics Malaysia (DOS, 2004), there were 192,527 establishments in the services sector in 2003 and 186,728 (or 96.7 per cent) of these were SMEs. As shown in Table 9, the majority of SMEs in the service sector were in the wholesale and retail trade industry, which accounted for 88.8 per cent of all service sector SMEs. The education and health services industry ranked next with a share of 4.5 per cent of SMEs. Table 9 also indicates that the participation of SMEs in the telecommunication services industry was limited due to the crucial requirements of large size of the firm or economies of scale.

\section{Insert Table 9 here}

Meanwhile, Table 10 presents the distribution of SMEs in the service sector by size of companies. The majority of SME enterprises in the service sector (59.6 per cent) are classified as micro size, followed by small (27.8 per cent), and medium (9.3 per cent). This classification will be used to analyze the contribution of SMEs in the service sector in the next section.

\section{Insert Table 10 here}

\subsubsection{The Contribution of SMEs in the Service Sector}

In comparison with the data available on SMEs in the manufacturing sector, the information on SMEs in the service sector is rather limited. Therefore, the size classification of Table 9 will be applied to the analysis of SMEs in the wholesale trade industry, the retail trade industry and the transportation and communication services industry only.

\section{a. The Wholesale Trade Industry}

According to Table 9, wholesale and retail trade is the largest segment, measured in numbers of establishments, of the services sector. The wholesale trade industry is the smaller of the two segments that constitute wholesale and retail trade, with 9.6 per cent of all SMEs involved in this sector. As indicated in Table 11, the SMEs here account for 84.3 per cent of all firms engaged (micro, small \& medium) in terms of sales turnover. The majority of enterprises, by a narrow margin, in this sector ( 35.7 per cent) are medium in size. The sector is characterised by low margins but high turnover

In terms of employment, the majority of SMEs in wholesale trade are small enterprises which employ between 5 to 19 workers. The importance of this industry rests in job creation and in providing linkages between production and consumption in the economy. The predominant forms of ownership are proprietorships and family-run businesses.

\section{Insert Table 11 here}

\section{b. The Retail Trade Industry}

Retail trade is the larger component of the wholesale and retail trade sector. As indicated in Table 12, 66.9 per cent of SMEs have a sales volume that qualifies for the micro classification of less than RM200,000. On the basis of the employment criterion, the bulk of SMEs also qualify as micro enterprises. As with the wholesale trade industry, this industry plays an important role of linking production and consumption and creating major employment opportunities. Ownership is also mostly in the form of sole proprietorships and family-run businesses. 


\section{Insert Table 12 here}

\section{c. The Transport and Telecommunication Services Industry}

Table 13 presents the profile of the transportation and communication services industry. The activities that fall under the transportation and communication services industry include logistics and freight forwarding services including shipping, storage and warehousing, road haulage, sea and inland transport, highway operations, courier services, public bus transport and car parking services. Similar to wholesale trade, the majority of SMEs here are classed as small to medium gauged by sales turnover and as small in terms of employment. The logistic services provide an important conduit for outsourced parts and components to move between the multinational enterprises and SMEs and also provide the linkages for intra industry trading.

\section{Insert Table 13 here}

\subsection{SMEs in Malaysia - Opportunities and Challenges}

Before discussing the opportunities open to the Malaysian SMEs, we review the macro perspective of the Malaysian economy as outlined in the Malaysian Third Industrial Master Plan 2006-2020 (IMP3). During the period of IMP3, the Malaysian economy is expected to grow at 6.3 percent per annum. As indicated by Table 14, beside the service sector, the manufacturing sector is expected to remain as an important sector with targeted annual growth of 5.6 percent per annum. Meanwhile in terms of share of GDP by sector, indicated in Table 15, the manufacturing sector is expected to contribute 28.5 percent of Malaysian GDP in 2020 and the service sector is to continue to be the major source of Malaysian economic growth with a 66.5 per cent share of GDP in 2020.

\section{Insert Table 14 here \\ Insert Table 15 here}

To achieve the targeted growth rate for manufacturing, IMP3 has identified 12 industries for greater development and promotion. These industries are listed in Table 16 - six of these industries are from the Resource Based industries while another six are from the Non-Resource Based industries. The selection of the industries was based on their strategic importance in terms of technological requirements, value-added, export, knowledge content, multiplier effect and potential to be integrated regionally and globally.

\section{Insert Table 16 here}

In the service sector, the non-Government services sector is targeted to lead growth during the period of IMP3 with 7.5 percent annual average growth compared to the Government service sector targeted average growth at 5.6 percent (Table 14). The government has targeted eight service sub-sectors to be promoted including business and professional services, logistics, ICT services, distributive trade, construction, education and training, healthcare and related services and tourism services.

\section{i. Opportunities in Manufacturing}

For the further development of SMEs in Malaysia, the traditional processing and production types of industries need to be enhanced. Table 17 presents selected knowledge-intensive industries in the manufacturing sector that represent areas in which Malaysian SMEs have a potential and competitive advantage.

\section{Insert Table 17 here}

\section{ii. Opportunities in the Services Sector}

At present, wholesale and retail trade has the highest concentration of SMEs in the services sector followed by education and health services (see Table 9). However, Table 18 identifies future potential prospects in the services sector that have wider opportunities for Malaysian SMEs to embark on during the IMP3 (2006-2020)

\section{Insert Table 18 here}

\section{iii. Challenges}

There were several impediments to the development of Malaysian SMEs which were identified during the IMP2 period. These weaknesses include the limited utilization of technology, limited involvement in R\&D activities, the lack of technical professional and management expertise and entrepreneurial skills, and the inability to explore market opportunities. Some of these weaknesses serve as challenges to Malaysian SMEs which need to be addressed to further strengthen the SMEs in the future.

In addition to the weaknesses that have been identified during the IMP2 period, there were also studies conducted to identify the constraints faced by Malaysian SMEs. For example, Table 19 provides a summary of 9 challenges faced by Malaysian SMEs based on the studies conducted by APEC (1994), SMIDEC (2002) and Ting (2004).

\section{Insert Table 19 here}


From Table 19, it is the evident that access to finance and human resource constraints are two common challenges faced by Malaysian SMEs. Access to finance includes the difficulties in accessing loans and other forms of financial assistance (APEC, 1994 and Ting, 2004), limited access to finance and capital and the infancy of venture funds in initial or mezzanine financing (SMIDEC, 2002). Meanwhile on the human resource constraint, the lack of skilled and talented workers affects the quality of production as well as efficiency and productivity (APEC, 1994), while the study from SMIDEC (2002) highlighted low productivity and quality output as challenges.

On the technology adaptation, SMIDEC (2002) has identified the limited capacity for technology management and knowledge acquisition from the source, while Ting (2004) has named the limitation or inability to adapt technology as the challenge. Both studies also named the intensified global competition as a challenge facing Malaysian SMEs. SMIDEC (2002) identified China and India as the two countries that Malaysian SMEs have to compete with in the future, due to their cheaper cost of production.

Finally the APEC (1994) study cites challenges that arise from inadequate government policies toward SMEs. These shortfalls include a lack of a comprehensive framework directed at SMEs' development, inconsistent definitions of SMEs, a multiplicity of agencies handling SMEs, and inadequate data and information on the development of Malaysian SMEs.

\section{Concluding Remark}

This chapter has examined the role of SMEs in the Malaysian economy. In particular, the discussion has concentrated on the contribution of SMEs in the manufacturing and the service sectors, followed by an outline of the opportunities and challenges that face Malaysian SMEs. These two sectors are major contributors to GDP and employment. Data constraints make it difficult to identify SME economic contribution directly but there is enough data to signal that the economic contribution is not inconsequential. For example, SME establishments dominate manufacturing and accounted for almost a third of manufacturing total output in 2003. On an industry level, the SME share of output varied from 30.6 per cent of food and beverages output to 2.2 per cent of textile and apparel output. SMEs also provide a significant amount of manufacturing employment varying from 16.6 per cent of food and beverages employment to 2.8 per cent in transportation. By and large, SME growth in both output and employment is solid. Within the services sector, an examination of wholesale trade, retail trade and transportation and telecommunications reveals that SMEs are responsible for the bulk of sales turnover and employment. In addition, these specifics point to the importance of SMEs in providing stimulus to economic growth, bridging backward and forward linkages between different sectors, expanding entrepreneurial bases and developing human capital. Since the majority of establishments in manufacturing and in services are SMEs, it makes economic sense to exploit their potential to further develop the Malaysian economy. It is important that Malaysian SMEs overcome the challenges that have been identified in order to capitalize on any new opportunities that arise. As outlined in the IMP3 and with the continuous support from the authority, there are many potential areas in the manufacturing and the service sectors that Malaysian SMEs should be able to successfully engage with considering the advantages that are already possessed by Malaysian SMEs.

\section{References}

APEC. (1994). The APEC Survey on Small and Medium Enterprises: Member Report Malaysia. [Online] Available: http://www.actetme.org/archive/smesurvey.html (Retrieved from August 26, 2008).

Department of Statistics. (2004). Annual Statistical Yearbook, Percetakan Nasional Malaysia Berhad, Kuala Lumpur, Malaysia.

Department of Statistics. (2005). Census 2005. Percetakan Nasional Malaysia Berhad, Kuala Lumpur, Malaysia.

Department of Statistics. (2006). Annual Statistical Yearbook, Percetakan Nasional Malaysia Berhad, Kuala Lumpur, Malaysia.

Fatimah, S. and Saad, M.S. (2002). Ekonomi Pasaran Buruh - Teori, Isu dan Peranan Kerajaan. A.Y. Publication, Kota Bharu, Malaysia.

Ministry of International Trade and Industry (MITI). (2005). Third Industrial Master Plan 2006 - 2020.

National Productivity Corporation (2004). Percetakan Nasional Malaysia Berhad, Kuala Lumpur, Malaysia.

SMIDEC. (2002). SME Performance Report. Small \& Medium Development Corporation, Percetakan Nasional Malaysia Berhad, Kuala Lumpur, Malaysia.

SMIDEC. (2004). SME Performance Report 2003. Small \& Medium Development Corporation, Percetakan Nasional Malaysia Berhad, Kuala Lumpur, Malaysia.

Ting, O.K. (2004). SMEs in Malaysia: Pivot Points for Change. [Online] Available: http://www/mca.org.my (Retrieved from August 26, 2008). 
Table 1. Contribution to GDP by Sector (1996, 2000 and 2005)

\begin{tabular}{|c|c|c|c|}
\hline \multirow{2}{*}{ Sector } & \multicolumn{3}{|c|}{ Contribution to GDP (\%) } \\
\cline { 2 - 4 } & 1996 & 2000 & 2005 \\
\hline Manufacturing & 29.1 & 31.9 & 31.4 \\
\hline Services & 50.7 & 53.9 & 58.1 \\
\hline Agriculture, forestry \& fishery & 9.8 & 8.9 & 8.2 \\
\hline Mining \& quarrying & 7.7 & 7.3 & 6.7 \\
\hline Construction & 4.7 & 3.3 & 2.7 \\
\hline (-) Imputed bank charges & 6.0 & 7.5 & 9.1 \\
\hline (+) Import duties Real GDP & 4.0 & 2.2 & 1.9 \\
\hline
\end{tabular}

Source: Department of Statistics, Census 2005

Table 2. Share of Employment by Sector (1996, 2000 and 2005)

\begin{tabular}{|c|c|c|c|c|}
\hline \multirow{2}{*}{ Sector } & \multicolumn{3}{|c|}{$\begin{array}{c}\text { Percentage } \\
\text { Share }\end{array}$} & $\begin{array}{c}\text { Percentage } \\
\text { Annual } \\
\text { Growth }\end{array}$ \\
\cline { 2 - 5 } & \multicolumn{2}{|c|}{} & 2005 & $1996-2005$ \\
\cline { 2 - 5 } & 1996 & 2000 & 28.7 & 4.4 \\
\hline Manufacturing & 26.2 & 27.7 & 51.0 & 4.1 \\
\hline Services & 46.2 & 48.8 & 12.9 & 0.6 \\
\hline Agriculture, forestry \& fishery & 17.7 & 15.3 & 0.4 & 0.5 \\
\hline Mining \& quarrying & 0.5 & 0.4 & 7.0 & 0.6 \\
\hline Construction & 9.5 & 8.1 & 100 & \\
\hline
\end{tabular}

Source: Department of Statistics, 2006

Table 3. Share of Export of Manufactured Products by Industry (1996, 2000 and 2005)

\begin{tabular}{|c|c|c|c|c|}
\hline \multirow[t]{2}{*}{ Industry } & \multicolumn{3}{|c|}{$\begin{array}{c}\text { Percentage } \\
\text { Share }\end{array}$} & \multirow{2}{*}{$\begin{array}{c}\text { Percentage } \\
\text { Growth }\end{array}$} \\
\hline & 1996 & 2000 & 2005 & \\
\hline Non-Resource Based & 81.9 & 85.9 & 82.4 & 11.1 \\
\hline - $\quad$ Electrical \& electronics products & 62.6 & 71.0 & 64.1 & 11.4 \\
\hline - Machinery, appliances and parts & 4.8 & 3.5 & 4.4 & 9.9 \\
\hline - Optical \& scientific equipments & 2.0 & 2.2 & 3.0 & 15.6 \\
\hline - $\quad$ Manufactures of metals & 2.4 & 2.2 & 2.6 & 11.7 \\
\hline - $\quad$ Textiles and apparel & 4.4 & 3.3 & 2.5 & 4.9 \\
\hline - $\quad$ Iron and steel products & 1.0 & 0.8 & 1.7 & 19.1 \\
\hline - $\quad$ Transport equipment & 3.0 & 1.0 & 1.7 & 2.9 \\
\hline - $\quad$ Manufactures of plastics & 1.0 & 1.2 & 1.6 & 16.8 \\
\hline - Jewellery & 0.7 & 0.8 & 0.9 & 11.8 \\
\hline Resource Based & 15.0 & 12.4 & 15.3 & 11.8 \\
\hline - $\quad$ Chemicals and chemical products & 3.8 & 4.2 & 6.4 & 17.4 \\
\hline - $\quad$ Wood products & 5.3 & 3.6 & 3.5 & 8.3 \\
\hline - $\quad$ Rubber products & 2.3 & 1.5 & 1.7 & 7.8 \\
\hline - $\quad$ Processed food & 1.5 & 1.1 & 1.6 & 10.8 \\
\hline
\end{tabular}




\begin{tabular}{|ll|c|c|c|c|}
\hline$\bullet \quad$ Non-metallic mineral products & 1.1 & 0.8 & 0.7 & 5.8 \\
\hline$\bullet \quad$ Petroleum products & 0.3 & 0.4 & 0.5 & 21.1 \\
\hline$\bullet \quad$ Paper and pulp products & 0.5 & 0.5 & 0.5 & 10.3 \\
\hline$\bullet \quad$ Beverages and tobacco & 0.4 & 0.4 & 0.4 & 15.7 \\
\hline \multicolumn{2}{|c|}{ Others } & $\mathbf{3 . 0}$ & $\mathbf{1 . 6}$ & $\mathbf{2 . 2}$ & $\mathbf{9 . 0}$ \\
\hline \multicolumn{2}{r|}{ Total } & $\mathbf{9 9 . 9}$ & $\mathbf{9 9 . 9}$ & $\mathbf{9 9 . 9}$ & \\
\hline
\end{tabular}

Source: Department of Statistics, 2006

Table 4. Distribution of SMEs in the Manufacturing Sector (by industry), 2003

\begin{tabular}{|c|c|c|c|c|}
\hline Industry & $\begin{array}{c}\text { Number } \\
\text { of establishments }\end{array}$ & $\begin{array}{c}\text { Number of } \\
\text { SMEs }\end{array}$ & $\begin{array}{c}\text { Proportion of } \\
\text { SMEs in the } \\
\text { Industry (\%) }\end{array}$ & $\begin{array}{c}\text { Proportion of } \\
\text { All SMEs } \\
\text { (per cent) }\end{array}$ \\
\hline Textiles and apparel & 3,419 & 3,319 & 97.1 & 18.2 \\
\hline Food and beverages & 2,949 & 2,749 & 93.2 & 15.2 \\
\hline Metal and metal products & 2,918 & 2,709 & 92.8 & 14.8 \\
\hline Wood and wood products & 2,776 & 2,582 & 93 & 14.1 \\
\hline Paper, printing, publishing & 1,288 & 1,195 & 92.8 & 6.5 \\
\hline Machinery and engineering & 1,249 & 1,135 & 90.9 & 6.2 \\
\hline Plastic products & 1,121 & 988 & 88.1 & 5.4 \\
\hline Electrical and electronics & 907 & 543 & 59.9 & 3.0 \\
\hline Non-metallic mineral products & 893 & 803 & 89.9 & 4.4 \\
\hline Other (jewellery) & 733 & 666 & 90.9 & 3.6 \\
\hline Petrochemical and chemical & 712 & 526 & 73.9 & 2.9 \\
\hline Transport equipment & 507 & 433 & 85.4 & 2.4 \\
\hline Rubber and rubber products & 482 & 366 & 75.9 & 2.0 \\
\hline Palm oil and palm oil products & 434 & 155 & 35.7 & 0.8 \\
\hline Leather & 67 & 65 & 97 & 0.4 \\
\hline Total & $\mathbf{2 0 , 4 5 5}$ & $\mathbf{1 8 , 2 7 1}$ & $\mathbf{8 9 . 3}$ & $\mathbf{1 0 0 . 0}$ \\
\hline
\end{tabular}

Source: SMIDEC, 2004

Table 5. Contribution of SMEs in the Manufacturing Sector

\begin{tabular}{|c|c|c|c|c|c|}
\hline & $\begin{array}{l}\text { Valu } \\
\text { (RM }\end{array}$ & Output & \begin{tabular}{|l} 
SME \\
Secto \\
Outp
\end{tabular} & Manufacturing & $\begin{array}{l}\text { Annual } \\
\text { Growth Rate } \\
(\%)\end{array}$ \\
\hline & 2002 & 2003 & 2002 & 2003 & 2003 \\
\hline Total Output & 62.8 & 68.9 & 29.1 & 29.1 & 9.7 \\
\hline Added Value & 12.7 & 14.2 & 25.8 & 26.1 & 11.8 \\
\hline
\end{tabular}

Source: National Productivity Corporation, 2004 
Table 6. Contributions to Output, Growth in Output, Value-Added Products and Growth in Value-Added Products by SMEs in the Manufacturing Sector, 2003

\begin{tabular}{|c|c|c|c|c|}
\hline Segment & $\begin{array}{c}\text { SME share of } \\
\text { Industry Output } \\
\text { (\%) }\end{array}$ & $\begin{array}{c}\text { Growth in Output } \\
\text { (\%) }\end{array}$ & $\begin{array}{c}\text { SME share } \\
\text { of Industry } \\
\text { Value-Added } \\
\text { Products (\%) }\end{array}$ & $\begin{array}{c}\text { Growth in } \\
\text { Value-Added } \\
\text { Products } \\
\text { (\%) }\end{array}$ \\
\hline Food and beverages & 30.6 & 9.1 & 19.8 & 16.3 \\
\hline Wood and wood products & 8.3 & $11.5 \%$ & 9.6 & 16.3 \\
\hline Rubber and plastic products & 10.8 & 8.8 & 12.2 & 13.3 \\
\hline Machinery and equipment & 2.9 & 8.9 & 4.2 & 11.3 \\
\hline Transportation & 2.5 & -2.3 & 3.3 & -0.5 \\
\hline Textile and apparels & 2.2 & $1.2 *$ & 3.2 & $4.7 \#$ \\
\hline Chemical and chemical products & 11.9 & 10.6 & 12.6 & 16.3 \\
\hline Metal and metal products & 13.6 & - & 13.9 & - \\
\hline Electrical and electronics (E\&E) & 5.2 & - & 5.1 & - \\
\hline Non-metallic mineral products & 4.8 & 10.5 & 6.6 & 13.7 \\
\hline
\end{tabular}

Source: National Productivity Corporation, 2004

" Inclusive of growth in both furniture (6.3) and wood and wood products (5.2).

- Inclusive of growth in both furniture (8.0) and wood and wood products (8.3).

* Growth in apparels was 2.0, while textiles had a -0.8 decline. Total growth was 1.2 for 'textiles and apparels'.

\# Growth in apparels was 3.5, while growth in textiles was 1.2. Total growth was 4.7 for 'textiles and apparels'.

Table 7. Employment Shares and Growth Rates of SMEs in the Manufacturing Sector, 2003

\begin{tabular}{|c|c|c|}
\hline Industry & $\begin{array}{c}\text { SME share of } \\
\text { Industry } \\
\text { Employment } \\
(\%)\end{array}$ & $\begin{array}{c}\text { Growth Rate of } \\
\text { SME Employment } \\
\text { (\%) }\end{array}$ \\
\hline Food and beverages & 16.6 & 3.5 \\
\hline Wood and wood products & 16.2 & 13.3 " \\
\hline Rubber and plastic products & 13.1 & 4.4 \\
\hline Machinery and equipments & 4.1 & -4.3 \\
\hline Transportation & 2.8 & 1.1 \\
\hline Textile and apparels & 7.2 & $-6.6 \#$ \\
\hline Chemical and chemical products & 5.3 & 10.3 \\
\hline Metal and metal products & 12.9 & - \\
\hline Electrical and electronics & 5.8 & - \\
\hline
\end{tabular}

Source: National Productivity Corporation, 2004

"Inclusive of growth in both furniture (11.4) and wood and wood products (1.9)

\# The total decline of -6.6 is a result of declines in both textiles (-3.3) and apparels (-3.3) 
Table 8. Labor Productivity of SMEs, 2003

\begin{tabular}{|c|c|c|}
\hline Labor Productivity & Value & Growth \\
\hline Output per employee (RM) & 183,222 & 5.6 \\
\hline Added value per employee (RM) & 37,675 & 7.8 \\
\hline Labour cost per employee (RM) & 18,762 & 7.3 \\
\hline Added value per labour cost (number) & 2.0 & 0.4 \\
\hline Unit labour cost (number) & 0.1 & 1.6 \\
\hline
\end{tabular}

Source: National Productivity Corporation, 2004

Table 9. Distribution of SMEs in the Services Sector (by Segment), 2003

\begin{tabular}{|c|c|c|c|c|}
\hline Segment & $\begin{array}{c}\text { Number of } \\
\text { Participating } \\
\text { Companies }\end{array}$ & $\begin{array}{c}\text { Number of } \\
\text { Participating SMEs }\end{array}$ & $\begin{array}{c}\text { Proportion of } \\
\text { SMEs in the } \\
\text { Segment } \\
\text { (per cent) }\end{array}$ & $\begin{array}{c}\text { Proportion of All } \\
\text { Participating } \\
\text { SMEs } \\
\text { (per cent) }\end{array}$ \\
\hline Education and health & & & \\
\hline Professional services & 8,558 & 8,438 & 98.6 & \\
\hline Selected services* & 5,548 & 4,840 & 87.2 & 2.6 \\
\hline Transportation and communication & 4,146 & 3,844 & 92.7 & 2.1 \\
\hline Computer industry services & 3,908 & 3,473 & 88.9 & 1.9 \\
\hline Wholesale and retail trade & 283 & 186 & 65.7 & 0.1 \\
\hline Telecommunications & 170,046 & 165,640 & 97.4 & 88.8 \\
\hline Total & 38 & 7 & 18.4 & 0.0 \\
\hline
\end{tabular}

Source: Department of Statistics, 2004

* Refers to hotels and other lodging places, travel agencies and tour operator services, share, commodity and foreign exchange brokers, bureau de change, real estate agents, video tape rental services, advertising agencies and motion picture projection services.

Table 10. Distribution of SMEs in the Services Sector by Size, 2003

\begin{tabular}{|c|c|c|}
\hline Size of Companies & Number of Companies & Share (\%) \\
\hline $\begin{array}{c}\text { Micro (Sales turnover } \leq \text { RM200,000 or }<5 \text { full-time } \\
\text { employees) }\end{array}$ & 114,840 & 59.6 \\
\hline $\begin{array}{c}\text { Small (Sales turnover between RM200,000 - RM1 } \\
\text { million or between 5 - 19 full-time) employees }\end{array}$ & 53,612 & 27.8 \\
\hline $\begin{array}{c}\text { Medium (Sales turnover between RM1 million - RM5 million } \\
\text { or between 20 - 50 full-time employees.) }\end{array}$ & 17,976 \\
\hline Total SMEs & 186,428 & 96.7 \\
\hline Large (> RM 5 million or $>50$ full time employee) & 6,099 & 3.2 \\
\hline Total & & 100 \\
\hline
\end{tabular}

Source: Department of Statistics, 2004 
Table 11. Profile of SMEs in the Wholesale Trade Industry 2003

\begin{tabular}{|c|c|c|c|c|c|c|}
\hline \multirow{2}{*}{ Category } & \multicolumn{3}{|c|}{ Employment } & \multicolumn{2}{c|}{ Sales Turnover } \\
\cline { 2 - 7 } & $\begin{array}{c}\text { Number } \\
\text { of Employees } \\
\text { Number } \\
\text { of SMEs }\end{array}$ & Percentage & $\begin{array}{c}\text { Category of Sales } \\
\text { Turnover (RM) }\end{array}$ & $\begin{array}{c}\text { Number } \\
\text { of SMEs }\end{array}$ & Percentage \\
\hline Micro & $<5$ & 6,508 & 39.7 & $<199,999$ & 2,396 & 14.6 \\
\hline Small & $5-19$ & 8,386 & 51.2 & 200,000 to & 5,566 & 34 \\
\hline Medium & $20-50$ & 1,094 & 6.7 & 1 million & & 3 million to \\
\hline Large & $>50$ & 398 & 2.4 & $>5$ million & 2,577 & 15.7 \\
\hline Total & & 16,386 & 100 & & 16,386 & 100 \\
\hline
\end{tabular}

Source: Department of Statistics, 2004.

Table 12. Profile of SMEs in the Retail Trade Sector, 2003

\begin{tabular}{|c|c|c|c|c|c|c|}
\hline \multirow[b]{2}{*}{ Category } & \multicolumn{3}{|c|}{ Employment } & \multicolumn{3}{|c|}{ Sales Turnover } \\
\hline & $\begin{array}{c}\text { Number } \\
\text { of Employees }\end{array}$ & $\begin{array}{l}\text { Number } \\
\text { of SMEs }\end{array}$ & Percentage & $\begin{array}{c}\text { Category } \\
\text { of Sales } \\
\text { Turnover }(R M)\end{array}$ & $\begin{array}{l}\text { Number } \\
\text { of SMEs }\end{array}$ & Percentage \\
\hline Micro & $<5$ & 130,773 & 85.1 & $<199,999$ & 102,852 & 66.9 \\
\hline Small & $5-19$ & 21,655 & 14.1 & $\begin{array}{l}200,000 \text { to } \\
1 \text { million }\end{array}$ & 40,459 & 26.3 \\
\hline Medium & $20-50$ & 816 & 0.5 & $\begin{array}{l}1 \quad \text { million to } \\
5 \text { million }\end{array}$ & 8,520 & 5.6 \\
\hline Large & $>50$ & 416 & 0.3 & $>5$ million & 1,829 & 1.2 \\
\hline Total & & 153,660 & 100 & & 153,660 & 100 \\
\hline
\end{tabular}

Source: Department of Statistics, 2004 
Table 13. Profile of SMEs in the Transportation and Communication Services Industry, 2003

\begin{tabular}{|c|c|c|c|c|c|c|}
\hline \multirow{2}{*}{ Category } & \multicolumn{3}{|c|}{ Employment } & \multicolumn{2}{c|}{ Sales Turnover } \\
\cline { 2 - 7 } & $\begin{array}{c}\text { Number } \\
\text { of Employees }\end{array}$ & $\begin{array}{c}\text { Number } \\
\text { of SMEs }\end{array}$ & Percentage & $\begin{array}{c}\text { Category } \\
\text { of Sales } \\
\text { Turnover (RM) }\end{array}$ & $\begin{array}{c}\text { Number } \\
\text { of SMEs }\end{array}$ & Percentage \\
\hline Micro & $<5$ & 694 & 17.8 & $<199,999$ & 773 & 19.7 \\
\hline Small & $5-19$ & 1,935 & 49.5 & 200,000 to & 1,429 & 36.5 \\
\hline Medium & $20-50$ & 834 & 21.4 & 1 million to & 1,271 & 32.5 \\
\hline Large & $>50$ & 445 & 11.3 & $>5$ million & 445 & 11.3 \\
\hline
\end{tabular}

Source: Department of Statistics, 2004

Table 14. Expected Average Annual Growth by Sector (2006 - 2020)

\begin{tabular}{|c|c|}
\hline Sector & $\begin{array}{c}\text { Average Annual Growth } \\
\text { (\%) }\end{array}$ \\
\hline Manufacturing & 5.6 \\
\hline Non-Government services & 7.5 \\
\hline Government services & 5.6 \\
\hline Agriculture, forestry and fishery & 5.2 \\
\hline Mining and quarrying & 3.4 \\
\hline Construction & 5.7 \\
\hline
\end{tabular}

Source: Ministry of International Trade and Industry, 2006

Table 15. Share of GDP by Sector (2005, 2010 and 2020)

\begin{tabular}{|c|c|c|c|}
\hline \multirow{2}{*}{ Sector } & \multicolumn{3}{|c|}{ Share of GDP (\%) } \\
\cline { 2 - 4 } & $\mathbf{2 0 0 5}$ & $\mathbf{2 0 1 0}$ & $\mathbf{2 0 2 0}$ \\
\hline Manufacturing & 31.4 & 32.4 & 28.5 \\
\hline Services & 58.1 & 59.2 & 66.5 \\
\hline Agriculture, forestry and fishery & 8.2 & 7.8 & 7.0 \\
\hline Mining and quarrying & 6.7 & 5.9 & 4.4 \\
\hline Construction & 2.7 & 2.4 & 2.5 \\
\hline
\end{tabular}

Source: Ministry of International Trade and Industry, 2006 
Table 16. Targeted Industries for Growth

\begin{tabular}{|c|ll|}
\hline \multicolumn{2}{|c|}{ Industry } \\
\hline \multirow{4}{*}{ Non-Resource Based } & 1. & Electrical and Electronics \\
\cline { 2 - 3 } & 2. & Medical Devices \\
\cline { 2 - 3 } & 3. & Textile and Apparel \\
\cline { 2 - 3 } & 4. & Machinery and Equipment \\
\cline { 2 - 3 } & 5. & Metal Industry \\
\cline { 2 - 3 } & 6. & Transport Equipment \\
\hline \multirow{5}{*}{ Resource Based } & & \\
\hline & 7. & Petrochemicals \\
\cline { 2 - 3 } & 8. & Pharmaceuticals \\
\cline { 2 - 3 } & 9. & Wood-Based Product \\
\cline { 2 - 3 } & 10. & Rubber and Rubber Product \\
\cline { 2 - 3 } & 12. & Oil Palm-Based Industry \\
\hline
\end{tabular}

Source: Ministry of International Trade and Industry, 2006 
Table 17. Industries and Potential Areas in Manufacturing Sector

\begin{tabular}{|c|c|}
\hline Industry & Potential Areas \\
\hline 1. Resource based & $\begin{array}{l}\text { - } \text { Herbal and traditional medicine } \\
\text { - } \quad \text { Cosmetics } \\
\text { - } \quad \text { Palm oil-based products } \\
\text { - } \quad \text { Wood based products } \\
\text { - } \quad \text { Food \& beverages, including convenience food } \\
\text { for the halal market }\end{array}$ \\
\hline 2. Machinery and engineering & $\begin{array}{l}\text { - } \\
\text { - } \\
\text { - }\end{array}$ \\
\hline 3. Electrical \& electronics & $\begin{array}{l}\text { - } \quad \text { Components for semi-conductors and radio } \\
\text { frequency identification } \\
\text { - } \quad \text { Precision stamping } \\
\text { - } \quad \text { D\&D of integrated circuits } \\
\text { - } \quad \text { High end printed circuit board assemblies } \\
\text { - } \quad \text { Substrates of printed circuit boards }\end{array}$ \\
\hline 4. Medical devices & $\begin{array}{l}\text { - Medical diagnostic devices and kits } \\
\text { - Medical and surgical disposable devices and } \\
\text { equipment }\end{array}$ \\
\hline 5. Manufacturing-related services & $\begin{array}{l}\text { - } \quad \text { Software development and software systems } \\
\text { integration } \\
\text { - } \quad \text { Mould design and texturing } \\
\text { - } \quad \text { Prototyping services } \\
\text { - } \quad \text { Burn-in or testing of integrated circuits } \\
\text { - } \quad \text { Failure analysis or repair centers for integrated } \\
\text { circuits, printed circuit boards and printed circuit } \\
\text { board assemblies. } \\
\text { - } \quad \text { Calibration and maintenance services } \\
\text { - } \quad \text { Surface mounting, using advance and } \\
\text { composite materials }\end{array}$ \\
\hline 6. Metal products & $\begin{array}{l}\text { - } \quad \text { Galvanized iron } \\
\text { - } \quad \text { Special steel including alloy steel and stainless } \\
\text { steel. }\end{array}$ \\
\hline
\end{tabular}

Source: Ministry of International Trade and Industry, 2006 
Table 18. Industries and Potential Areas in Services Sector

\begin{tabular}{|c|c|}
\hline Industry & Potential Areas \\
\hline 1. Distributive trade & $\begin{array}{ll}\text { - } & \text { Retail } \\
\text { - } & \text { wholesale } \\
\text { - } & \text { restaurants } \\
\text { - } & \text { motor vehicle distribution } \\
\text { - } & \text { motor vehicle trade \& repair services } \\
\text { - } & \text { franchising }\end{array}$ \\
\hline 2. Transport services \& Logistic & $\begin{array}{ll}\text { - } & \text { Forwarding } \\
\text { - } & \text { Packaging } \\
\text { - } & \text { Haulage } \\
\text { - } & \text { Warehousing } \\
\text { - } & \text { Storage } \\
\text { - } & \text { Bulk breaking } \\
\text { - } & \text { Integrated logistics supply chain }\end{array}$ \\
\hline 3. Tourism services & $\begin{array}{ll}\text { - } & \text { Hotels } \\
\text { - } & \text { Transportation } \\
\text { - } & \text { Eco-tourism } \\
\text { - } & \text { Agro-tourism } \\
\text { - } & \text { Health tourism } \\
\text { - } & \text { Edu-tourism }\end{array}$ \\
\hline 4. Professional and Business services & $\begin{array}{ll}\text { - } & \text { Human resource management } \\
\text { - } & \text { Market research } \\
\text { - } & \text { Management consultancy } \\
\text { - } & \text { Advertising } \\
\text { - } & \text { Legal } \\
\text { - } & \text { Accounting, book-keeping, auditing and tax } \\
\text { consultancy } \\
\text { - } & \text { Architectural } \\
\text { - } & \text { Engineering } \\
\text { - } & \text { R \& D } \\
\text { - } & \text { Environment and energy }\end{array}$ \\
\hline 5. Education \& Training & $\begin{array}{l}\text { - } \quad \text { Courses on new } \\
\text { technologies/methods/processes/technical standards } \\
\text { - } \quad \text { Entrepreneurship } \\
\text { - } \quad \text { Professional accredited courses }\end{array}$ \\
\hline 6. Construction & $\begin{array}{l}\text { - Civil engineering (metal works, electrical } \\
\text { works, plumbing, sewerage and sanitary works, } \\
\text { refrigeration and air conditioning works, painting } \\
\text { works, carpentry, tiling and flooring and glass } \\
\text { work) To adopt clustering approach in bidding for } \\
\text { projects by combining complementary skills and } \\
\text { expertise especially in civil engineering } \\
\text { - } \quad \text { Residential and non-residential construction } \\
\text { - Infrastructure }\end{array}$ \\
\hline 7. ICT & $\begin{array}{l}\text { - } \text { Customized software development } \\
\text { - } \quad \text { Consultancy in e-commerce } \\
\text { - } \quad \text { Consultancy in security }\end{array}$ \\
\hline
\end{tabular}

Source: Ministry of International Trade and Industry, 2006 
Table 19. The Malaysian SMEs Challenges

\begin{tabular}{|l|l|l|l|l|}
\hline Challenges & APEC & SMIDEC & Ting \\
\hline 1. Access to finance & & $\sqrt{ }$ & $\sqrt{ }$ & $\sqrt{ }$ \\
\hline 2. Human resource constraints & $\sqrt{ }$ & $\sqrt{ }$ & $\sqrt{ }$ \\
\hline 3. $\quad$ Technology adaptation & & $\sqrt{ }$ & $\sqrt{ }$ \\
\hline 4. $\quad$ Global competition & & $\sqrt{ }$ & $\sqrt{ }$ \\
\hline 5. Lack of knowledge \& information & $\sqrt{ }$ & \\
\hline 6. Lack of comprehensive SMI policies & $\sqrt{ }$ & \\
\hline 7. Inconsistent definitions of SMEs & $\sqrt{ }$ & & \\
\hline $8 . \quad$ Many agencies dealing with SMEs & $\sqrt{ }$ & & \\
\hline 9. Inadequate data on SMEs & $\sqrt{ }$ & & \\
\hline
\end{tabular}

Sources: APEC (1994), SMIDEC (2002) and Ting (2004) 